\title{
HUBUNGAN HYGIENE SANITASI PENGELOLAAN MAKANAN DENGAN JUMLAH ANGKA KUMAN PADA MIE GANYONG YANG DIPRODUKSI OLEH HOME INDUSTRY DI DESA MAJASARI KECAMATAN BUKATEJA KABUPATEN PURBALINGGA TAHUN 2015
}

\author{
Aryani Khoirun Nisa'), Mawaddah' ${ }^{2)}$ \\ Jurusan Kesehatan Lingkungan, Politeknik Kesehatan Kemenkes Semarang, \\ Jl. Raya Baturaden KM 12 Purwokerto, Indonesia
}

\begin{abstract}
Abstrak
Ganyong adalah tumbuhan penghasil umbi dimanfaatkan menjadi produk olahan mie ganyong. Jenis penelitian observasi dan pendekatan cross sectionaldenganUjiStatistik Spearman. Hasil pemeriksaan angka kuman pada empat produsen memenuhi syarat dengan standart $1 \times 10^{6} \mathrm{koloni} / \mathrm{g}$. Hasil responden A sampel baru $\left(4,6 \times 10^{5}\right.$ koloni/g), sampel lama $\left(3.4 \times 10^{4} \mathrm{koloni} / \mathrm{g}\right)$. Responden B sampel baru $\left(3.6 \times 10^{5} \mathrm{koloni} / \mathrm{g}\right)$, sampel lama $\left(1,3 \times 10^{4}\right.$ koloni/g). Responden C sampel baru $\left(5.2 \times 10^{5} \mathrm{koloni} / \mathrm{g}\right)$, sampel lama $\left(1,4 \times 10^{4} \mathrm{koloni} / \mathrm{g}\right)$. Responden D sampel baru $\left(3,9 \times 10^{5} \mathrm{koloni} / \mathrm{g}\right)$, sampel lama $\left(6,7 \times 10^{4} \mathrm{koloni} / \mathrm{g}\right)$.Disimpulkan bahwa hygiene sanitasi pengelolaan mie ganyong sudah cukup baik (presentasi 57,8\%). Hasil uji statistik pada sampel rata-rata 0,04, dibandingkan dengan a 0.05 maka $0.04<0,05$. Ho ditolak dan Ha diterima berarti ada hubungan hygiene sanitasi pengelolaan makanan dengan jumlah angka kuman pada mie ganyong yang diproduksi oleh home industry di Desa Majasari. Untuk penjamah mie ganyong sebaiknya mengolah mie ganyong dimeja yang bersih, menjaga personal hygiene seperti mencuci tangan sebelum dan sesudah mengolah mie ganyong.
\end{abstract}

Kata Kunci : Hygiene sanitasi pengelolaan mie ganyong, kesehatanlingkungan

\begin{abstract}
Canna is a tuber-producing plants utilized as a noodle product canna. Types of observational studies and cross-sectional approach. Results of the examination number of bacteria on the four producers qualified with a standard $1 \times 10^{6}$ colonies $/ g$. Results A new sample of respondents $\left(4.6 \times 10^{5}\right.$ colonies $\left./ g\right)$, the old sample $\left(3.4 \times 10^{4}\right.$ colonies $/ g)$. Respondents B new samples $\left(3.6 \times 10^{5}\right.$ colonies $\left./ g\right)$, the sample is long $\left(1.3 \times 10^{4}\right.$ colonies $\left./ g\right)$. Respondents new sample $C\left(5.2 \times 10^{5}\right.$ colonies $\left./ g\right)$, the sample is long $\left(1.4 \times 10^{4}\right.$ colonies $\left./ g\right)$. Respondents $D$ new samples $\left(3.9 \times 10^{5}\right.$ colonies $/ g)$, the sample is long $\left(6.7 \times 10^{4}\right.$ colonies $\left./ g\right)$. It was concluded that the management of sanitary hygiene canna noodles are good enough (presentation 57.8\%). Results of statistical tests on the sample average of 0.04, compared with 0.05 then 0:04 $\alpha<0.05$. Ho rejected and Ha accepted means no relationship hygiene sanitation food to the number of germs on canna noodles produced by home industry in the village Majasari. To handlers noodle noodles canna canna should cultivate the table clean, maintain personal hygiene such as washing hands before and after treating the noodles canna.
\end{abstract}

Keywords : sanitation hygiene management canna noodles, environmental health

\section{Pendahuluan}

Hygiene sanitasi makanan dan minuman adalah upaya untuk mengendalikan faktor tempat, peralatan, orang dan makanan yang dapat atau mungkin dapat menimbulkan gangguan kesehatan dan keracunan makanan melalui 6 (enam) prinsip pengolahan makanan yang meliputi penyediaan bahan makanan, penyimpanan bahan makanan, pengolahan makanan, pengangkutan makanan, penyimpanan makanan serta penyajian makanan (Depkes RI, 2004).

Ganyong (Canna edulis ker) adalah sejenis tumbuhan penghasil umbi yang menjadi produk olahan salah satunya adalah mie ganyong.

1) E-mail : aryani.nisaa@yahoo.com

2) E-mail: mawaddah50@gmail.com
Berdasarkan penelitian awal yang dilakukan bahwa mie ganyong mulai dibuat pada tahun 2001 . Pada home industry ini ada 4 (empat) produsen yang membuat mie ganyong. Mengenai kondisi sanitasi tempat pembuatan mie ganyong pengolahan mie ganyong masih dilakukan dilantai, penjamah kurang memperhatikan personal hygiene, penjamah masih berkuku panjang, tempat penjemuran mie ganyong disebelah jalan raya, di sebelah tanah yang becek, diinjak-injak oleh bebek dan ayam yang memungkinkan terkontaminasi mikroorganisme ke dalam mie ganyong. Peneliti merumuskan masalah penelitian "Hubungan Hygiene Sanitasi Pengelolaan 
Makanan dengan Jumlah Angka Kuman pada Mie Ganyong yang Diproduksi oleh Home Industry di Desa Majasari Kecamatan Bukateja Kabupaten Purbalingga Tahun 2015".

Tujuan penelitian adalah mengetahui hubungan hygiene sanitasi pengelolaan makanan dengan jumlah angka kuman pada mie ganyong yang diproduksi oleh home industry di Desa Majasari.

\section{BAHAN DAN METODE}

Jenis penelitian ini adalah penelitian observasi dan pendekatan cross sectional, yaitu penelitian dilakukan pada waktu tertentu dan mengetahui hubungan antara variabel bebas dan variabel terikat dengan Uji Spearman.

\section{III.HASIL DAN PEMBAHASAN}

Hygiene sanitasi pengelolaan makanan pada mie ganyong yang diproduksi oleh Home Industry di Desa Majasari didapatkan hasil observasi atau pengamatan dan wawancara dengan menggunakaan instrument pengumpulan data berupa checklist dan kuesioner pada responden A didapat nilai akhir 52,95 $\%$ dengan kategori kurang baik, pada responden B didapat nilai akhir $78,7 \%$ dengan kategori baik, responden C didapat nilai $45,15 \%$ dengan kategori Kurang Baik, Responden D didapatnilaiakhir 59,55\% dengan kategori Cukup Baik, dengan nilai rata-rata 57,8\% dengan kategori cukup baik.

Hasil pengukuran pencahayaan dengan Lux meter :

\begin{tabular}{cccl}
\hline Responden & $\begin{array}{c}\text { Hasil } \\
\text { Pengukuran }\end{array}$ & $\begin{array}{c}\text { Standart } \\
\text { pencahayaan }\end{array}$ & Kategori \\
\hline $\mathrm{A}$ & $15 \mathrm{fc}$ & & TMS \\
$\mathrm{B}$ & $18 \mathrm{fc}$ & 20 & TMS \\
$\mathrm{C}$ & $14 \mathrm{fc}$ & food candle & TMS \\
$\mathrm{D}$ & $17 \mathrm{fc}$ & & TMS \\
\hline
\end{tabular}

Keterangan :

MS : Memenuhi Syarat

TMS : Tidak Memenuhi Syarat

Jumlah Angka Kuman pada Mie Ganyong

\begin{tabular}{cccc}
\hline Kode \\
Sampel & $\begin{array}{c}\text { Hasil } \\
\text { koloni/g }\end{array}$ & $\begin{array}{c}\text { Standar } \\
\text { (koloni/g) }\end{array}$ & Keterangan \\
\hline $\mathrm{A}$ & $4,6 \times 10^{5}$ & & Memenuhi syarat \\
$\mathrm{B}$ & $3,6 \times 10^{5}$ & & Memenuhi syarat \\
$\mathrm{C}$ & $5,2 \times 10^{5}$ & & Memenuhi syarat \\
$\mathrm{D}$ & $3,9 \times 10^{5}$ & $1 \times 10^{6}$ & Memenuhi syarat \\
$\mathrm{A} 1$ & $3,4 \times 10^{4}$ & & Memenuhi syarat \\
$\mathrm{B} 1$ & $1,3 \times 10^{4}$ & Memenuhi syarat \\
$\mathrm{C} 1$ & $1,4 \times 10^{4}$ & Memenuhi syarat \\
$\mathrm{D} 1$ & $6,7 \times 10^{4}$ & Memenuhi syarat \\
\hline
\end{tabular}

Keterangan :

A, B, C, D : Sampel baru langsung diperiksa

A11, B1, C1, D1 : Sampel disimpan 1 minggu

Hasil Uji Statistik dengan Uji Spearman pada sampel rata-rata diketahui bahwa sig hubungan hygiene sanitasi pengelolaan makanan dengan jumlah angka kuman adalah 0,04, jika dibandingkan dengan $\alpha 0,05$ maka $0,04<0,05$. Ha ditolak dan Ha diterima berarti ada hubungan hubungan hygiene sanitasi pengelolaan makanan dengan jumlah anhka kuman pada mie ganyong yang diproduksi oleh home industry di Desa Majasari Kecamatan Bukateja.

Upaya pemecahan masalah hygiene sanitasi pengelolaan mie ganyong yang diproduksi oleh home industry sebagai berikut :

1. Lantai yang kotor dan tidak membentuk konus sebaiknya dilakukan perbaikan terhadap setiap pertemuan sudut-sudut antara lantai dan dinding harus konus (melengkung bulat atau tidak membentuk sudut mati), sedangkan untuk kondisi lantai yang kotor sebaiknya dijaga kebersihannya sebelum dan sesudah melakukan aktifitas dengan melakukan kebersihan secara rutin setiap hari diperlukan.DengantujuanUntuk mencegah adanya pencemaran oleh mikroorganisme atau kotoran yang ada dilantai.

2. Ventilasi tidak berfungsi dengan baik $(<10 \%$ dari luas lantai) dan tidak menghilangkan bau tidak sedap sebaiknya Pengaturan ventilasi diperbanyak $10 \%$ dari luas lantai dengan tujuan untuk menghilangkan bau tidak sedap diruang pengolahan mie.

3. Pencahayaan tidak memenuhi persyaratan Keputusan Menteri Kesehatan Republik Indonesia Nomor 1098/Menkes/SK/VII/2003 yaitu $20 \mathrm{fc}$ (foot candle)sebaiknyaUntuk dapat melihat dengan jelas kotoran bisa memudahkan dalam pembersihan tempat.

4. Tidak terdapat langit-langit pada tempat pengelolaan mie ganyong sebaiknya dilakukan perbaikan dengan memasang langit-langit rumah yang tidak rawan kecelakaan, mudah dibersihkan, kedap air dan dijaga kebersihan langit-langit dari sarang laba-laba seminggu sekali secara rutindengantujuanUntuk menghindari debu yang berada diatap jatuh ketempat pengolahan mie ganyong dan menghindari binatang pengganggu.

5. Pintu yang tidak rapat tikus sebaiknya pintu dibuat rapat tikus dan dipasangi terali untuk menghindari adanya tikus keluar masukdengantujuan untuk menghindari adanya tikus dan binatang pengganggu lainnya yang masuk ke tempat pengelolaan mie ganyong.

6. Pembuangan air limbah yang tidaktertutup, sebaiknya saluran pembuangan air limbah dibuat tertutup dan kedap air, dan alangkah lebih baik apabila ada pengolahan lebih lanjuttujuanTidak menjadi perkembangbiakan vektor dan binatang seperti lalat dan tikus.

7. Toilet kotor dan letaknya berhubungan langsung dengan dapur atau tempat pengelolaan mie ganyong sebaiknya Toilet dijaga kebersihannya dengan dibersihkan secara rutin setiap seminggu sekali dan sebaiknya letaknya tidah berhubungan langsung dengan dapur atau tempat pengelolaan mie ganyong.

8. Tempat sampah yang tidak tertutup dan tidak kedap air sebaiknya tempat sampah disediakan 
yang tertutup agar tidak menimbulkan bau, dan tempat sampah kedap air.

9. Tempat pencucian peralatan tidak sesuai dengan persyaratan kesehatan sebaiknya Tempat pencucian peralatan sebaiknya sesuai dengan persyaratan kesehatan dan tempat pengeringan peralatan dibersihkan secara rutin.

10. Tidak terdapat tempat peralatan untuk mencegah masuknya serangga dan tikus sebaiknya terdapat peralatan untuk mencegah masuknya serangga dan tikus, diantaranya kawat kassa serangga, terali tikus, dan tendon air yang bebas jentik nyamuk, dll.

11. Tempat penyimpanan bahan baku tidak terawat, tidak disusun dalam rak-rak dan tidak bebas dari binatang pengganggu sebaiknya tempat penyimpanan bahan baku dijaga kebersihanya setiap seminggu sekali secara rutin dan terpelihara serta cara penyimpanan sebaiknya sejenis atau tidak tercampur.

12. Tidak terdapat fasilitas penyimpanan makanan dingin (kulkas, freezer) dan tidak terdapat cerobong asapsebaiknyadapur disediakan pembuangan asap yaitu cerobong asap dan sebaiknya terdapat fasilitas penyimpanan makanan dingin (kulkas, freezer).

13. Pengolahan mie ganyong dilakuakan di lantai sebaiknya pengolahan mie ganyong tidak dilakukan dilantai.

14. Pengangkutan dari tempat pengolahan ke tempat penjemuran melewati sumber pencemar, alat yang digunakan untuk mengangkut mie ganyong terbukasebaiknyaSebaiknya pengangkutan mie ganyong ketempat penjemuran tertutup.

15. Penjemuran dilakukan ditepi jalan raya dan disebelah tanah yang becek sebaiknya penjemuran dibuatkan tempat jarak dengan tanah $1 \mathrm{~m}$.

16. Penyimpanan mie ganyong tidak tertutup sebaiknya tempat penyimpanan mie ganyong tertutup.

17. Penjamah makanan tidak mencuci tangan dengan sabun sebelum dan sesudah bekerja, tidak menutup mulut dengan sapu tangan saat bersin atau batuksebaiknyadalam melakukan aktivitas penjamah makanan mencuci tangan dengan sabun sebelum maupun sesudah bekerja, menutup mulut dengan sapu tangan bila batuk atau bersin.

18. Penjamah tidak pernah mengikuti kursus mengenai cara pengolahan mie ganyong sebaiknya penjamah mengikuti kursus mengenai cara pengolahan bahan makanan.

\section{IV.KESIMPULAN}

Hasil penilaian hygiene sanitasi pengelolaan mie ganyong di Desa Majasari Kecamatan Bukateja Kabupaten Purbalingga tahun 2015 secara keseluruhan termasuk kategori cukup baik dengan nilai rata-rata adalah $58,7 \%$.

Hasil pemeriksaan jumlah angka kuman pada empat produsen yang diambil tiap produsen sebanyak
2 sampel mie ganyong dengan jumlah sampel 8 mie ganyong yang diproduksi oleh home industry di Desa Majasari memenuhi syarat dengan standart $1 \times 10^{6}$ koloni/g. Pada responden A sampel baru $\left(4,6 \times 10^{5}\right.$ koloni/g), sampel lama (3.4 x $10^{4}$ koloni/g). Responden B sampel baru (3.6 x $10^{5}$ koloni/g), sampel lama $\left(1,3 \times 10^{4} \mathrm{koloni} / \mathrm{g}\right)$. Responden $\mathrm{C}$ sampel baru $\left(5.2 \times 10^{5} \mathrm{koloni} / \mathrm{g}\right)$, sampel lama $(1,4 \mathrm{x}$ $10^{4}$ koloni/g). Responden D sampel baru (3,9 x $10^{5}$ koloni/g), sampel lama (6,7 x 10 $10^{4}$ koloni/g).

Berdasarkan hasil uji statistik pada sampel ratarata 0,04 , dibandingkan dengan $\alpha 0.05$ maka $0.04<$ 0,05 . Ho ditolak dan Ha diterima berarti ada hubungan hygiene sanitasi pengelolaan makanan dengan jumlah angka kuman pada mie ganyong yang diproduksi oleh home industry di Desa Majasari.

\section{DAFTAR PUSTAKA}

Aris Santjaka. (2011). Statistik Untuk Penelitian Kesehatan 1. Yogyakarta

Depkes RI. (2004).Pengertian Hygiene Sanitasi Makanan dan Prinsip-Prinsip Hygiene Sanitasi Makanan.

Dini Destria.(2012).Hubungan Hygiene Sanitasi Pengelolaan Makanan Dan Miniman Dengan Jumlah Bakteri Coliform Pada Es Krim Tradisional Yang Dibuat Prosedur Di Wilayah Kerja Puskesmas Cilacap Tengah I Kabupaten Cilacap Tahun 2012. KTI. Purwokerto:Poltekkes Kemenkes Semarang Jurusan Kesehatan Lingkungan.

Direktori Jurnal Prodi Tata Boga.(2009). Pemanfaatan Ganyong (Canna Edulis) Pada Pembuatan Mie Segar sebagai Upaya Panganekaragaman Pangan Non Beras, Jakarta.

Keputusan Menteri Kesehatan RI/No. 1098/Menkes/SK/VII/2003. Tentang Persyaratan Higiene Sanitasi Rumah Makan dan Restoran.

Lucia Tri Pangesthi.(2009).Pemanfaatan Pati Ganyong (Canna Edulis) Pada Pembuatan Mie Segar Sebagai Upaya Penganekaragaman Pangan Non Beras. Media Pendidika Gizi dan Kuliner. UNESA.
Peraturan Kepala Badan POM Ri No. HK.00.06.1.52.4011, 2009.Tentang Penetapan Batas Maksimum Cemaran Mikroba dan Kimia Dalam Makanan.

Peraturan Pemerintah Republik Indonesia No. 28. (2004) pasal 5, Tentang Keamanan, Mutudan Gizi Pangan. 
Peraturan Presiden Republik Indonesia No. 72. (2012). Tentang Sistem Kesehatan Nasional.

Pusat Pengembangan Teknologi Pangan. (1989)Pati Ganyong Paket Industri pangan. IPB, Bogor.

Siregar. (2009). Kriteria mikroorganisme yang banyak digunakan untuk mengetahui kualitas makanan, Jakarta.

Suharsimi Arikunto, 1998, Managemen Penelitian, Jakarta: Rineka Cipta.

Tri Cahyono. (2014). Pedoman Penulisan Proposal Penelitian dan Karya Tulis Ilmiah (Edisi Revisi Ketiga), Poltekkes Kemenkes Semarang Jurusan Kesehatan Lingkungan Purwokerto.

Undang-Undang No. 36 tahun 2009 pasal 162 tentang Kesehatan 